\title{
Amanda Anthony \\ ENTREPRENEURIAL UNIVERSITIES AND REGIONAL DEVELOPMENT: POLICY ORIGINS, PROGRESS, AND THE FUTURE, WITH A FOCUS ON POLAND
}

DOI: $10.1515 /$ ppsr-2015-0013

\begin{abstract}
University entrepreneurship is an idea that has gained a significant amount of support globally in the last 30 years and is seen as promoting reinvention, revitalisation, and simply remuneration for the universities themselves and their regions at large. But as universities begin to ramp up their technology transfer activities and start to commercialise their research, it is important to consider the regional context and the regional impacts that this can have. Technology transfer is important, but to truly transform economic "catch-up" regions to future leading regions, it cannot be the only goal of university entrepreneurship. As a result, larger perspective and more government, business, and university collaboration is needed. Using Poland as a focus area, this paper will summarise the concept and development of the entrepreneurial university and the policies needed for success, and show that the technology transfer activity of the university should be considered just one element of regional development strategies. It concludes with policy recommendations that may be useful for Poland and other regions.
\end{abstract}

Keywords: education policy, innovation policy, entrepreneurial universities, regional development, regional policy, technology transfer

\section{Introduction}

Academic entrepreneurship and the concept of the entrepreneurial university have been well defined in both international and Polish literature. (Clark 1998; Gibb \& Hannon 2006; Etzkowitz \& Leydesdorff 2000; Kwiek 2008; Wright et al 2007; Szumigalska \& Anthony 2013). However, broad implementation of the tenets of academic entrepreneurship has generally lagged despite professed desires to adopt them, both in Europe and in the United States. This paper aims to review the state of affairs in Poland and its leading regions through the lens of academic entrepreneurship. Using Poland as a frame, as well as existing literature, it will, first, summarise the concept and development of the entrepreneurial university; second, delineate the necessary conditions for its operation; and third, prove that the technology transfer activity of the university should be considered just one element of regional development policy.

\section{Background}

In Europe, adoption and implementation of academic entrepreneurship at university level is still in progress among regions in "economic catch-up positions" (Youtie \& Shapiro 
2008, 1192) - regions in former Communist countries, regions outside capital cities, or even former steel, textile, and manufacturing-heavy regions - that are looking to establish themselves as good investments for international companies and the European Investment Fund. The European Union and European Commission have included innovation and research, and support for small- and medium-sized enterprises (SMEs) as funding priorities. However, less-developed European regions are not expected to prioritise expenditure on these areas to the same level as more-developed regions - and in fact, they do not. Poland, for example, spent the majority of its cohesion funds on infrastructure and international cooperation rather than on innovation policy. Nevertheless, as developing economies with room to innovate, catch-up regions in Poland and elsewhere are likely to become the next focus of European investors. For one, many of these regions do not suffer from the old economy, "lock-in" effect (Tödtling \& Trippl 2005, 1210), although many of them may suffer from problems of weakly developed potential (1212). They also represent a considerable source of educated young people and overall purchasing power.

As an example, Poland has been the only economy in Europe to post positive growth for each of the last five years, and it was recently rated 14th overall (10th excluding disaggregated Chinese cities) on the OECD Programme for International Student Assessment of 15-year-olds (OECD PISA 2013). In higher education, the OECD Education at a Glance indicators show that although Polish university students have lower completion rates than other countries, they also send more students to university (OECD 2013, 69). In fact, the number of students going to university has increased by more than $500 \%$ since 1990 , with 1.9 million attending in 2010 compared with 4 million in 1990 (Kwiek 2013, 34).

One should note that taking advantage of the fertile ground for growth may mean a shift in approach to research and innovation, as well as a different orientation to expansion. A recent European Commission report shows that the Czech Republic, Slovakia, Lithuania, and Hungary are only "moderate" innovators, with Latvia and Poland being "modest" (Hollanders 2013, 10). Previous research has shown that small-business owners in many Central and Eastern European countries lack the mind-set necessary to start high-growth, high-yield companies (Degroof \& Roberts 2004, 5). Research in Poland particularly shows that a large share of the SMEs that exist are "survival-oriented, or necessity-based entrepreneurship, as opposed to growth-oriented, or opportunity-based entrepreneurship" (Woodward et al 2010, 7).

Second, technology transfer infrastructure exists at many universities but often lacks the entrepreneurial approach of seeking out opportunities for partnership and development. This is partially because researchers in these countries do not always consider themselves as business developers, and partially because the concept of entrepreneurship being led by the university (and not the state) is quite new (Degroof \& Roberts 2004, 5). In Poland, a report by the Ministry of Science and Higher Education found that

$20 \%$ of companies did not know that that it was possible to cooperate with the academic community, and 40\% of companies had never tried to get in touch with universities. Also $40 \%$ of surveyed companies did not know how to reach research centres potentially interested in the commercialisation of research. At the same time, surprisingly, almost half 
of the companies surveyed that actually got in touch with scientists (45\%) reported that the initiative for cooperation came from the scientists. Companies involved in partnerships with universities were generally satisfied; the effects of cooperation with scientists were rated as rather positive by $51 \%$ and definitely positive by $17 \%$ of respondents. Only 3\% of surveyed companies provided a "rather negative" or "definitely negative" assessment of a university partnership (MNISW 2006, 4-10, cited in Kwiek 2013, 33).

It is evident that this problem does not only refer to Poland. One should note that the findings are consistent with the results of a 2011 survey conducted by Todd Davey and Victoria Galan Muros on the state of European University-Business Cooperation (UBC), which found that UBC is seen as a crucial activity, but that one out of every three highereducation institutions engage in no or little UBC activity. Two out of five academics are responsible for the majority of UBC (Davey \& Muros 2012). According to Jacek Guliński, the undersecretary of state for the Ministry of Science and Higher Education, three universities in Poland make up 75\% of the technology transfer activities, and the majority of technology transfer activities are still in the realm of training rather than licensing or development (Kieraciński 2013). In part, this real and perceived low level of research output and regional development drove the 2011 changes to the higher education law, to put incentives and mechanisms in place to encourage UBC and regional engagement (Kwiek 2013, 32 and 35).

The third challenge for universities in Central and Eastern Europe, or any catch-up region, will be avoiding the mistakes of their Western predecessors in taking a too-narrow view of university entrepreneurship and regional development. As many universities have recognised the benefits of being more entrepreneurial, they have included innovation statements into their mission, established science parks to commercialise researchers' ideas, and engaged in other knowledge transfer activities. The most developed aspect of university-region linkage in Poland, for example, is on the teaching dimension (Kwiek 2013, 30). However, one may observe that the benefits risk stopping at the universities' - or even the professors' - doorsteps, going no further than reputation building or consulting (Degroof \& Roberts 2004, 19). In Poland, quite often discoveries made by Polish scientists have not been commercialised or have been taken abroad to do so (Kieraciński 2013).

In a keynote speech at the 2012 Entrepreneurial Universities Conference in Munster, Germany, the president of Twente University, Anne Flierman, specifically mentioned the university's orientation towards regional development - and not only towards technology and knowledge transfer - as being a lesson learned through their innovation process. Rather than viewing the university as the "centre of gravity", it is better to view it as "part of the pie" (Flierman 2012, 16).

Thus, when considering innovation in "catch-up regions", regional innovation should be adopted as the driving mind-set. It should be possible to use the best practices collected from across the US and Europe to create regional development plans that have, as a core element, an entrepreneurial university (Etzkowitz \& Klofsten 2005, 245). According to Bercowitz and Feldman $(2006,175)$, having an entrepreneurial university is not a necessary condition for regional growth but that it contributes greatly to such plans. 
Currently, there are no fully entrepreneurial universities in Poland, although many universities have begun to engage in technology transfer and other regionally focused activities. Despite the fact that there has been an increasingly greater emphasis on UBC and university engagement from the Polish Agency for Enterprise Development and other agencies, as shown by recent reports on the state of Regional Innovation Systems and University Business Cooperation (PARP 2013a; PARP 2013b; Kwiek 2013, 30; Orłowski 2013; PARP 2005), there are still many regional development plans which have not fully incorporated or fully realised the concepts of knowledge transfer and academic entrepreneurship.

\section{The rise of the entrepreneurial university and its role in knowledge transfer: literature review}

Knowledge transfer between universities, businesses, and government was largely onedirectional in its early stages in the US. "The traditional role ... was independent creation of knowledge beyond direct control of the government" (Gibb, Haskins \& Robertson 2009, 11). Although the government funded higher education, it was typically at the state level through block grants funded by tax dollars (Rosenberg 2009, 114; Gibb \& Hannon 2006, 15), and it often followed this cycle: university graduates would gain experience and skills, business would benefit from having a more highly-educated workforce, and employees' tax dollars would go back into investing in higher education.

But at the end of the Second World War, a new element of knowledge transfer was introduced when new industries began to develop. While Europe was rebuilding, the US was experimenting with the new fields of computer science and biotechnology. Universities such as Stanford and MIT initially, and Texas and North Carolina later (Gibb \& Hannon 2006,3) began to recruit industry leaders to teach classes, to provide internships or cooperative education opportunities for current students, and to otherwise engage in the university environment. For a time, this kind of university-industry partnership represented the ideal of university entrepreneurship - universities were still knowledge creators, and industry was still a knowledge commercialiser.

The next phase was influenced by direct funding cuts at the federal and state level. As a result, universities had to pay more attention to technology transfer and the monetisation of their research as a way to close the funding gap. This led to the development of the current "entrepreneurial university" - a university which is quick to develop new courses on relevant, timely topics, which acts as a business developer, and which even works with government and industry leaders to identify partnerships and growth plans for the region that include contributions by all three groups. (Gibb, Haskins and Robertson 2009, 12; Kwiek 2008, 760).

Etzkowitz and Leydesdorff $(2000,111)$ describe this situation using the Triple Helix model, in which the university, government, and industry no longer work in nonintersecting spheres but instead take on roles of the other, with hybrid organisations emerging at the interfaces. In the most advanced cases, the university is also perceived as the anchor of a "regional innovation hub" - a centre of industrial development (Gibb, Haskins 
and Robertson 2009, 11-12). When this transformation occurs, knowledge transfer shifts from a more linear model to a more complex one. In the past, the transfer had rested on "market pull" or "technology push", both insufficient for free-flowing transfers (Etzkowitz \& Leydesdorff 2000, 110). As the complexity rose, so did the need for cooperation between universities and government.

One of the main questions that arose was that of intellectual property (hereafter IP), i.e., who possessed it, who could commercialise it, and what the terms were. In the US, problems were mitigated by the Bayh-Dole Act, which awarded the IP to a federally funded research organisation instead of university or company. This meant that the government, under the auspices of the National Science Foundation (NSF), played a role in setting up the Industry \& University Cooperative Research Program (Hodges 2001, 1), and other programmes, which formalised the relationship between the two actors.

In Poland, the recently revised Higher Education Act outlines that in the case of a university that has created a science centre or other cooperative research centre, it must be written in the cooperation contract to whom the intellectual property rights are assigned. In the case of a university which is itself commercialising research, a "special purpose vehicle" in the form of a limited liability company or joint stock company also may be used to protect IP (Higher Education Act, Art. 31; Art 86a). A 2013 report from PwC Polska indicates that the assignment of IP to the university instead of the scientist was one of limiting factors in the development of ground-breaking research in Poland (Orłowski $2013,5,22)$ and recommends full assignment of IP to the scientist or inventor. However, in view of the research on successful entrepreneurial universities, which requires a high level of cooperation between researchers, their universities, and businesses, it seems that this may not have the desired effect, as businesses are unlikely or unable to pay the necessary price for taking advantage of the invention. It also appears that the recent legal revisions did not incorporate this recommendation.

Regarding national research organisations, Poland has in place the National Centre for Research and Development (NCBiR), established in 2007 to support innovative science policy with a focus on the "reinforcement of cooperation between Polish business circles and scientists and intensification of the commercialization of research results". The NCBiR funds research through several interdisciplinary grant programmes, including INNOTECH, whose goal is to connect scientists with Polish companies, and could serve as the basis for formalised cooperation.

\section{Investing in entrepreneurial activity}

It is important to note that solving the intellectual property issue did not lead to immediate commercialisation of research. This is in part caused by the fact that companies based on emerging research have a high risk of transfer failure, thus it is still expensive to spin them off (Rosenberg 2009, 117). To do so successfully, there must be both a reliable and risk-loving set of resources to support the transformation of ideas to reality. At odds with this is the fact that most private venture capitalists seek to recoup their investments and conservatively invest in only the most promising research; even when working with 
university development offices, they typically "compel founders to submit business plans showing rapid positive cash flow. In so doing, they pushed founders even more to adopt a contract-based business model" (Degroof \& Roberts 2004, 19), which had the effect of limiting commercialisation.

A strength of university entrepreneurship, wherein universities absorb some of the risk of commercialisation by relying on a combination of government and private funding, is that it allows researchers to take more risks. In fact, a diversified funding base is one of the core components of university entrepreneurship, with the other four being a strengthened steering core, an expanded developmental periphery, a stimulated academic heartland, and an integrated academic culture (Clark 1998, 5). Rosenberg shows that relying on government development support and knowing that the founder will not have to absorb all losses should make starting a business easier (Rosenberg 2009, 4), although lacking the proper entrepreneurial infrastructure within the universities could limit the amount of spin-off activity (Degroof \& Roberts 2004, 32).

The most recent research from the OECD is based on a 1999 survey of government information about spin-offs in Europe, which showed that at that time it was still a technology transfer transaction with little impact (Callan 2001). In the US, however, spin-off activity remained a strong driver of knowledge transfer. The Association of University Technology Managers (AUTM) released the FY2012 annual licensing survey, which shows that 705 new startups were created that year, an increase of 5\% over FY2011, with 554 of them staying local and starting in the same place as they were licensed, an increase of almost $14 \%$. Besides this, more than 4,000 startups that had been started in previous years were still operational. Newly added to the survey in FY2011 was a question about the number of full-time employees (FTE) at startup companies. In FY2012, the 70 institutions that responded reported a total of 15,741 FTE working in startups.

\section{University entrepreneurship and technology transfer in Poland}

Despite a growing interest in technology transfer, data about knowledge transfer activities, including spin-offs, was difficult to find and, where found, inconsistently reported or reported without clear definitions. Data were not consistently available on the number of spin-off firms established, the term of operation of these firms, and the number of employees. Streamlining data reporting procedures, which occurred with the Association for University Technology Managers in the US, would help orient universities towards knowledge transfer and entrepreneurship by giving them a basis for comparison with their peers. Working with common definitions and reporting structure could help the universities overcome the problems they report with a perceived lack of entrepreneurial mind-set at all levels of the university.

Another challenge reported regarding knowledge transfer and university entrepreneurship was found in a 2011 survey of Polish higher education institutions, where managers indicated that they perceived themselves and their environments to be among the least oriented to university-business cooperation and facing many funding barriers (Davey 2013). It appears that more effort has been directed towards overcoming the funding 
barriers than changing the mind-set. However, through programmes such as NCBiR's SPIN-TECH programme, which supports state research units (universities, research institutes, and the Polish Academy of Sciences), test their technology's commercialisation transferability over a period of two to three years. This reduces the risks of spinning off a company and enhances partnership possibilities by giving the innovator a chance to connect meaningfully with developers and investors.

The programme complements universities' own entrepreneurial activities. A report from the Polish Agency for Enterprise Development shows that in 2011, Lesser Poland (Małopolska), Lower Silesia (Dolny Śląsk), and Greater Poland (Wielkopolska) had the greatest concentration of innovation centres in Poland (PARP2011,9). The Central Statistical Office ranks Warsaw, Poznan, and Upper Silesia as spending the most on innovation (Woodward 2010, 10). And the Ministry of Science and Higher Education specifically recognised three universities as having higher-than-average levels of technology transfer: the Academy of Mining and Metallurgy (AGH, Kraków, Małopolska) the Jagiellonian University (Kraków, Małopolska), and Wrocław University of Technology (Wrocław, Lower Silesia). A key recipient of NCBiR funds, AGH has also tried to mitigate funding barriers to innovation by creating INNOAGH, the Centre for Innovative Technology, which is $100 \%$ owned by AGH and serves as a university investment fund. The only one of its kind, it both provides advice as well as funding for researchers interested in innovation, and is the best example of university-supported funding to be found in Poland.

\section{The necessary conditions for improving university entrepreneurship (spin-off activity in particular)}

In an examination of the main issues and determinants of building a climate of entrepreneurship, O'Shea et al. (2005, 995), highlight three strands of research: 1) the personal characteristics of academics, including the importance of independence; 2) the influence of universities' policies, procedures, and practices on commercialisation, with a focus on reward systems, staffing, and resources; 3) environmental factors impacting academic innovation, such as the presence of venture capital and intellectual property protection mechanisms. The main findings indicate that entrepreneurial universities have strong leadership that develops entrepreneurial capacity for all students and staff, strong ties with external stakeholders, innovative learning techniques that inspire entrepreneurship, open boundaries that allow for knowledge flow between organisations, and multidisciplinary approaches to education (Arnaut 2010, 4).

When considering Poland's universities in this manner, one may note that significant progress is necessary for transformation. According to the survey on university-business collaboration (Davey 2013, 1), Polish academics and higher education institution managers rated themselves highly on curriculum development and learning, but very low on collaboration and commercialisation of $\mathrm{R} \& \mathrm{D}$, which form two major aspects of the entrepreneurial university. First, there is a reported lack of funding both at the university level and externally, and a high need for relational trust in order to engage in knowledge transfer. Second, there is a lack of perceived benefits to entrepreneurship 
and a lack of incentives for promoting academic entrepreneurship. Other research on the innovativeness of European countries also points to a low innovation environment in Poland. The European Commission rates Poland in the middle of the pack on finance and support for research as well as firm investments, but in the bottom three in Europe for open, excellent, and attractive research systems, linkages and entrepreneurship, and innovators (Hollanders 2013, 18). Whatever early progress is being made in technology transfer at Polish universities must be complemented by other development strategies human capital, funding, and internal training, among others, to reach the entrepreneurial university ideal.

It is also worth briefly discussing the importance of path dependency on spinoff activity. O'Shea, et al. $(2005,1002)$, use the concept of path dependency to describe why entrepreneurial universities such as MIT and Stanford continue to be leaders in startups. The culture in place, based on past success, has led to these universities nurturing an entrepreneurial mind-set and developing on-going incentives to promote entrepreneurship. As a result, three of the top five universities - Stanford and MIT included - have maintained a top-five ranking in spinoff activity at every evaluation period. And although the data show that only four universities that were outside of the top 40 in the period 1980-1995 entered the top 20 in 1995-2001, it does indicate that the path can start at any time. The most impressive transformation came from the California Institute of Technology, which was responsible for just two spinoffs from 1980-1995 but 67 from 1995-2001.

The amount of federal funding spent on science and engineering, especially in the areas of life science, chemistry, and computer science, also matters in supporting spin-off activity. The higher the funding received, the larger number of spin-offs per university. Interestingly, the presence of a university-affiliated incubator was not significant to the number of spin-offs (1003).

Regarding the case of Poland, one should stress that more funding be directed towards $\mathrm{R} \& \mathrm{D}$, which is a stated goal of the NCBiR and the Ministry of Science and Higher Education (Kieraciński 2013), although still only $0.8 \%$ of GDP is currently directed towards it. The second important implication for Polish universities is to take care to implement highselectivity, high-support policies for fostering spin-offs, as getting started on the right path is essential for future success (Degroof \& Roberts 2004, 31). Finally, expectations must be reasonable, based on the Polish institutional environment - change will not happen overnight (Kwiek 2013, 37).

\section{Technology transfer and the entrepreneurial university as a part of regional development policy}

The research referenced above shows that one of the key components of the transformation to a entrepreneurial university - going from a "knowledge factory" to a "knowledge hub" - is a high level of technology transfer. This transfer can take many transactional forms - sponsored research, training, consulting, licensing, spin-off firms, and the hiring of students (Bercovitz \& Feldmann 2006, 176). It can be challenging for many reasons, with the primary reason being the differential missions of university and 
industry. Nevertheless, if the focus is there, one would "expect to see a progression from single transactions to longer-term relationships as trust and joint vision are built" (182).

These on-going transfer activities can be a component of an innovating region, but they cannot be the totality. Johns Hopkins University in the US is a prime example of a university engaged in a high level of knowledge transfer that does not contribute significantly to the regional economy (Youtie \& Shapiro 2008, 1102; Bercovitz \& Feldman $2006,181)$. It is not the only university in such a position. For universities that wish to capitalise commercially on their research, it shows the importance of drawing on regional strengths as the university transforms.

This idea was articulated well by Anne Flierman from Twente University: an innovating region, i.e., a region that has designed a development plan around innovation, with the entrepreneurial university at its core, cannot rely solely on this university. The university must be a piece of the pie, not the whole pie. An innovating region typically has multiple "nodes of research strength, including universities, government laboratories, non-profit research organizations, and private sector R\&D units" (Youtie \& Shapiro 2008, 1102). Innovating regions may see the university as an anchor to attract private R\&D activity and should encourage partnerships between the university (or universities) and regional private business, as well as supporting spin-off activity at the university alone. Where these partnerships are lacking, it can result in an entrepreneurial university with high technology transfer but low contribution to the regional economy.

Choosing the initial theme of the university's entrepreneurship focus should be considered in the context of the region. While a truly entrepreneurial university embeds the concept in its everyday activities, research in science, engineering, and technology have proven easier to commercialise than other fields. But in their haste to develop "innovating regions", many policymakers have taken an ineffective "one-size-fits-all" approach to innovation. Tödtling and Trippl write that although the concept of the entrepreneurial university has "without a doubt many good and interesting elements ... it is often used in an undifferentiated manner for all different kinds of regions. The specific strengths and weaknesses of regions in terms of their industries, knowledge institutions, innovation potential, and problems are frequently not sufficiently taken into account" $(2005,1204)$.

Drawing on local needs, industries, and strengths is one of the reasons AGH in Kraków has been comparatively successful in its efforts to commercialise research - the university is working in partnership with local industry and taking into account local needs as it conducts technology transfer. But this example shows us that scope also matters. As AGH is heavily focused on one industry, it may not be enough to make a huge regional difference even though it works on a regional strength. Finding the right scope - not too narrowly focused on one industry, and not so broad as to dilute resources and expertise is thus an essential part of the regional development plan. If the entrepreneurial university is considered a piece of the regional development pie, then different frameworks for innovation should be employed based on regional status - peripheral regions which lack dynamic clusters and support organisations, old industrial regions where the main innovations come in process rather than product, and fragmented metropolitan regions where the lack of networks and interactive learning work against regional innovation 
(1209-1211). Based on the university's resource stocks and the region's strengths, more comprehensive regional development plans can be initiated.

Poland has a special set of challenges to face in developing regional innovation plans centred around an entrepreneurial university, because unlike the US and other countries in Europe, the higher education market is fragmented and the economy and institutional environment are still developing (Kwiek 2012). With each region encompassing many technical institutes and specialised universities - one for economics, one for natural sciences, and one for mining and metallurgy, as an example - Poland's plans cannot rely on one university alone. Therefore, its regional plans should incorporate a healthy amount of cooperation between universities while also promoting technology transfer between university and industry. This inter-university cooperation can be difficult due to intellectual property concerns, overlapping areas of interest, and differential goals at the university level.

Presuming these cooperative barriers can be overcome, each region then must strive to attract innovative firms and leading global companies while strengthening its "endogenous potential" (Tödtling and Trippl 2005, 1212). A focus on regional strengths is necessary, although the 2020 and 2030 Polish regional development plans focused almost exclusively on four areas of innovation: nanotechnology, biotechnology, biomedicine, and information technology. Although it is possible that all the top regions in Poland count these areas among their strengths, it is more likely that these are simply "hot topics"; thus, more differentiation is necessary and possible.

\section{Conclusion and policy recommendations}

Research and case studies from around the world show that universities that are becoming more entrepreneurial is an inevitable and positive trend. Building a culture of flexibility and creativity - the core elements of entrepreneurship - is necessary for universities to stay relevant in an ever-changing world, although it is not enough for transformation to the entrepreneurial ideal. For the "catch-up regions" of Europe, of which Poland has many, the entrepreneurial university can serve as an innovation station - collaboratively building the endogenous potential so that the region is no longer catching up, but leading.

When looking at Poland through the lens of technology transfer and regional innovation policy and examining the level of university entrepreneurship therein, evidence shows that a significant amount of work still needs to be done in three areas: 1) building incentives for entrepreneurship both at the university level and the regional level; 2) expanding funding sources and linking entrepreneurs to funders more effectively; and 3) creating linkages between universities and businesses at an earlier stage and maintaining them longer.

The incentives for entrepreneurship could take many forms at the university level. Instead of assigning tenure or promotions based on publishing alone, universities could reward researchers for their entrepreneurial activities. There could be financial bonuses for researchers who engage in partnerships with business or who pursue patents and other desired transfer activity. They could receive protected time off from university duties to pursue entrepreneurial activities in the region - training other researchers, mentoring 
students, participating in regional strategic planning with government, and serving on loan in startup businesses. They could even be freer to set their research and teaching priorities - recognising their entrepreneurial mind-set with increased independence.

Regionally, the vouchers for an innovation programme in Lower Silesia and the "Innovation Małopolski" programme in Małopolska are good examples of regional incentives; however, we know from Lower Silesia's own research that more support is needed to support entrepreneurship in all reviewed regions. This could take the form of an "entrepreneurship residency", where entrepreneurially minded researchers from around the region apply to work on specific projects, work in specific companies, or pursue their own projects. There could be government support for placing researchers, doctoral students, and even undergraduate students in innovative companies in order to experience what innovation looks like on a daily basis. It could even be a repurposing of Erasmus funds to sponsor internships or cooperative education programmes for students from across the region, with an emphasis on student-led startups, which would have the potential to instil the mind-set of entrepreneurship in the next generation of regional leaders.

The second major barrier to overcome is the funding and the linkages to funding. Poland has a weak venture capital economy, thus innovative funding schemes like crowdfunding, microfinance, and graduated lending could be used for stronger effect and ongoing support to startups. Another area that appears underdeveloped in Polish universities compared to American universities is the connection with alumni. Developing stronger alumni affinity organisations at university level would lead to new sources of funding that could be used to foster entrepreneurial activities.

To address the third challenge, Polish governments must continue to encourage universities and business to engage more frequently and more strategically, perhaps with incentives. If university graduates are not adequately prepared for work, then business leaders should be willing and invited to collaborate on innovative curricula and courses. In return, businesses could provide internships on a larger range of topics or start postgraduate rotational programmes that give students and young alumni more opportunity to engage with innovative work environments. Finally, external organisations could help bridge the gap - for example, non-profits that are bringing together professors and managers to collaborate and co-learn, foundations that are supporting specific work streams with financial or human capital support, and even governmental departments that are evaluated on regional growth factors and collaboration statistics.

Finally, regional development plans should focus more on the specific strengths of the region and outline clear roles for different universities, research institutes, and businesses receiving government support via tax reductions or other incentives. What is known about entrepreneurial universities is that the roles should blur, so the plans should allow for universities and government to be more business-like, for businesses and government to be more research-driven, and for universities and businesses to be more regionally focused. At a national level, Poland should put a continued focus on increasing research and development funds as well as promoting entrepreneurial activities at all levels of the economy, with a focus on incentivising entrepreneurial university activity. Although a university cannot become entrepreneurial overnight, the benefits of entrepreneurship, 
and even the entrepreneurial mind-set, on the regional and ultimately national economy are tangible and worth pursuing.

\section{References}

Arnaut, D. (2010). 'Towards an Entrepreneurial University'. International Journal of EuroMediterranean Studies. Vol. 3, No. 1, pp. 135-152. Available at <http://www.emuni.si/ press/ISSN/1855-3362/3_135-152.pdf $>$. [Accessed 25 February 2014].

Association of University Technology Managers. 'AUTM Licensing Activity Survey: FY2012'. Available at <http://www.autm.net/FY2012_Licensing_Activity_Survey/12357. htm.> [Accessed 25 February 2014].

Bercovitz, J. \& Feldmann, M. (2006). 'Entrepreneurial Universities and Technology Transfer: A Conceptual Framework for Understanding Knowledge-Based Economic Development'. Journal of Technology Transfer. Vol. 31, pp. 175-188.

Callan, B. (2001). 'Generating spin-offs: evidence from the OECD'. Science Technology Industry Review. Special issue on fostering high tech spin-offs: a public strategy for innovation, Vol. 26, pp. 13-56.

Clark, B. (1998). Creating Entrepreneurial Universities: organizational pathways of transformation. New York: Pergamon Press.

Davey, T. (2013). 'The State of University-Business Cooperation in Poland'. Available at $<$ http://www.ub-cooperation.eu/pdf/poland.pdf > [Accessed 25 February 2014].

Davey, T. \& Muro, V. (2012). 'The State of European University-Business Cooperation'. Conference Material, Entrepreneurial Universities 2012 Conference. Available at $<$ http://entrepreneurial-universities.com/pdf/Todd\%20Davey.pdf> [Accessed 25 February 2014].

Degroof, J. \& Roberts, E. (2004). 'Overcoming weak entrepreneurial infrastructures for academic spin-off ventures'. Journal of Technology Transfer. Vol. 29, No. 3-4, pp. 327-352.

Etkowitz, H. \& Klofsten, M. (2005). 'The innovating region: toward a theory of knowledgebased regional development'. R\&D Management. Vol. 35, No. 3, pp. 243-255.

Etzkowitz, H. \& Leydesdorff, L. (2000). 'The dynamics of innovation: from National Systems and "Mode 2" to a Triple Helix of university-industry-government relations'. Research Policy. Vol. 29, pp. 109-123.

Flierman, A. (2012). 'How to become an entrepreneurial university'. Conference Material, Entrepreneurial Universities 2012 Conference. Available at $<\mathrm{http}$ ://entrepreneurialuniversities.com/pdf/Anne\%20Flierman.pdf> [Accessed 25 February 2014].

Gibb, A. \& Hannon, P. (2006). 'Toward an Entrepreneurial University'. International Review of Entrepreneurship. Vol. 4, pp. 73.

Gibb A., Haskins, G. \& Robertson, I. (ed.) (2009). 'Leading the Entrepreneurial University: Meeting the entrepreneurial needs of higher education institutions'. Conference Material, The National Council of Graduate Entrepreneurship. Available at $<$ http:// www.ncee.org.uk/publication/leading_the_entrepreneurial_university.pdf $>$ [Accessed 25 February 2014]. 
Higher Education Act (2005, Revised 2014). Available at <http://www.bip.nauka.gov.pl/g2/ oryginal/2014_03/4ee4d7fcecla100d8ee3e690fb4cd09d.pdf> [Accessed 29 June 2014].

Hodges, D. (2001). 'Industry-University Cooperation and the Emergence of Start-Up Companies'. REITI Policy Symposium. Available at <http://www.rieti.go.jp/en/ events/01121101/Hodges_final.pdf $>$ [Accessed 25 February 2014].

Hollanders, H. \& Es-Sadki, N. (2013). 'Innovation Union Scorecard 2013'. Available at $<$ http://ec.europa.eu/enterprise/policies/innovation/files/ius-2013_en.pdf> [Accessed 25 February 2014].

Kieraciński, P. (2013). Interview with Dr. Jacek Guliński: "Naszym Celem jest innowacja gospodarka". Available at <http://forumakademickie.pl/fa/2013/06/naszym-celemjest-innowacyjna-gospodarka/> [Accessed 25 February 2014].

Kwiek, M. (2008). 'Academic Entrepreneurship vs. Changing Governance and Institutional Management Structures at Universities. Policy Futures in Education, Vol. 6, No. 6, pp. 757-770.

Kwiek, M. (2013). 'Polish Universities, Their Regions and Their Impact on Economic Growth'. Człowiek i społeczeństwo. Vol. 35.

Kwiek, M. (2012). Universities, Regional Development and Economic Competitiveness: the Polish Case. In: Pinheiro R., Benneworth, P. \& Jones, G. eds. Universities and Regional Development. A Critical Assessment of Tensions and Contradictions. New York: Routledge. 69-85.

OECD (2013). Education at a Glance 2013: OECD Indicators. OECD Publishing. Available at http://dx.doi.org/10.1787/eag-2013-en. [Accessed 25 February 2014].

OECD PISA (2013). Available at http://www.oecd.org/pisa/keyfindings/PISA-2012results-snapshot-Volume-I-ENG.pdf. [Accessed 25 February 2014].

O’Shea, R., et al. (2005). 'Entrepreneurial Orientation, technology transfer, and spinoff performance of U.S. universities'. Research Policy. Vol. 34, pp. 994-1009.

Orłowski, W. (2013). 'Komercjalizacja Badań Naukowych w Polsce'. PwC Polska, July 2013. Available at <http://www.ncbir.pl/gfx/ncbir/userfiles/_public/aktualnosci/ komercjalizacja_badan_naukowych_w_polsce_-_prof._w._orlowski.pdf> [Accessed 28 April 2014].

PARP: Polish Agency for Enterprise Development (2011). 'Innovation Centers in Poland'. Available at <http://www.pi.gov.pl/PARPFiles/file/OIB/publikacje/Osrodki_ innowacji_w_Polsce_ENG.pdf $>$ [Accessed 25 February 2014].

PARP: Polish Agency for Enterprise Development (2013). 'Regional Innovation Systems in Poland'. Available at <http://www.parp.gov.pl/index/more/31287> [Accessed 21 May 2014].

PARP: Polish Agency for Enterprise Development (2013). 'Cooperation of Science and Business'. Available at <http://www.parp.gov.pl/index/more/38265> [Accessed 21 May 2014].

PARP: Polish Agency for Enterprise Development (2005). 'Innovative Academic Entrepreneurship: A World of Experience'. Available at <http://www.dcsr.wroc.pl/files/ File/Publikacje/innowacyjna_przeds_akadem.pdf $>$ [Accessed 21 May 2014]. 
Ministerstwo Rozwoju Regionalnego (2011). 'Poland 2011: Economy - Society - Regions'. Available at <http://www.mir.gov.pl/rozwoj_regionalny/Ewaluacja_i_analizy/ Raporty_o_rozwoju/Raporty_krajowe/Documents/Synteza_Raport_\%20Polska_2011_ ang_04052012.pdf> [Accessed 3 May 2014].

Rosenberg N. (2009). America's Entrepreneurial Universities. In: Hart, D. ed. The Emergence of Entrepreneurship Policy. Cambridge: Cambridge University Press, pp. 113-138.

Szumigalska, A. \& Anthony, A. (2013). 'The Development of the Concept of Academic Entrepreneurship: The Case of The United States'. Wrocławskie Studia Politologiczne, Vol. 15, p. 92-104.

Tödtling, F. \& Trippl, M. (2005). 'One size fits all? Towards a differentiated regional innovation policy approach'. Vol. 34, pp. 1203-1219.

Woodward, R., Yoruk, D., Koc, P. \& Pander, W. (2010). 'Knowledge-based entrepreneurship in Poland'. CASE Network Studies and Analyses, No. 408.

Wright, M., Clarysse, B., Mustar, P. \& Lockett, A. (2007). Academic Entrepreneurship in Europe. Cheltenham: Edward Elgar Publishing Limited.

Youtie, J. \& Shapiro, P. (2008). 'Building an innovation hub: A case study of the transformation of university roles in regional technological and economic development'. Research Policy. Vol. 37, pp. 1188-1204.

\section{Web Pages}

Cracow University of Technology: http://www.transfer.edu.pl/

'Entrepreneur in residence': http://en.wikipedia.org/wiki/Entrepreneur_in_residence

European Cohesion Funds (European Commission): http://ec.europa.eu/regional_policy/ thefunds/regional/index_en.cfm

GDP: http://data.worldbank.org/indicator/NY.GDP.MKTP.KD.ZG

INNOAGH: http://www.innoagh.pl/en/o-nas/

The Jagiellonian University: http://www.cittru.uj.edu.pl/

National Centre for Research and Development (NCBiR, Poland): http://www.ncbir.pl/

NCBiR SPIN-TECH: http://www.ncbir.pl/programy-krajowe/spin-tech/

National Strategy for Regional Development (Poland): http://www.mir.gov.pl/english/ Regional_Development/Regional_Policy/NSRD/doc_str/Documents/KSRR_EN_1_ DKS.pdf

Wrocław University of Technology: http://www.wctt.pl/ 